\title{
ОЦІНКА СІМЕЙНОї СИТУАЦІї ТА МАТЕРИНСЬКО-ДИТЯЧИХ ВІДНОСИН ОЧИМА ДІТЕЙ MATЕРІВ, ХВОРИХ НА ПАРАНОÏДНУ ШИЗОФРЕНІЮ
}

\author{
๑М. О. Дрюченко
}

\section{Ужгородський національний університет МОН України}

\begin{abstract}
РЕЗЮМЕ. Вивчення особливостей сімейного функціонування та материнсько-дитячих відносин з точки зору дітей матерів, хворих на параноїдну шизофренію (ПШ). На базіпсихіатричноговідділення Закарпатського обласного наркологічного диспансеру протягом 2014-2016 рр. обстежено 100 жінок, хворих на ПШ, та 112 їх дітей (12 жінок мали двох дітей). Жінки були обстежені за допомогою клініко-психопатологічного та психодіагностичного методів, діти - з використанням проективної методики «Кінетичний малюнок сім'ї». Визначено тісний зв'язок порушень сімейного функціонування і сприйняття дитиною родинної ситуації з тяжкістю психопатологічної симптоматики у матерів, хворих на ПШ. У дітей, матері яких хворі на ПШ, виявлено значуще нижчі показники сімейного

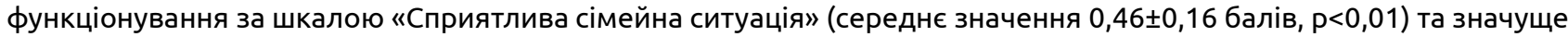
вищі показники за шкалами «Тривожність» $(0,97 \pm 0,24$ балів, $p<0,01)$, «Конфліктність у сім'ї» $(1,02 \pm 0,27$ балів, p<0,01), «Почуття неповноцінності у сімейній ситуації» $(0,98 \pm 0,21$ балів, $p<0,01)$, «Ворожість у сімейній ситуації» $(0,95 \pm 0,21$ балів, p<0,01), що свідчить про наявність дисоціації у материнсько-дитячій взаємодії та деформації сімейного функціонування в родинах, де мати хворіє на ПШ. Наявність тяжкого психічного захворювання на ПШ у матері суттєво впливала на стан психоемоційної сфери дитини і спричиняла глибокі порушення сімейного функціонування. Отримані дані були покладені нами в основу розробки системи медико-психологічних заходів оптимізації материнсько-дитячої взаємодії у жінок, хворих на Пш.
\end{abstract}

КЛЮчОВІ СЛОВА: параноїдна шизофренія, мати, оцінка дитиною сімейної ситуації, дитячо-материнські відносини.

Вступ. Параноїдна шизофренія (ПШ) $є$ тяжким психічним захворюванням, яке чинить виразний деструктивний вплив на всі сфери соціального функціонування людини [1-4]. Тому на сьогодні все більшого значення набувають дослідження, які вивчають стан хворих на ПШ у суспільстві, оскільки це дозволяє більш обґрунтовано підходити до розробки програм психосоціальної реабілітації залежно не тільки від вираженості шизофренічного процесу, але з урахуванням гендерних особливостей функціонування хворих на шизофренію [5]. Крім того, все більшої актуальності набувають питання надання допомоги хворим в позалікарняних умовах, де важлива роль належить сімейному оточенню [6 - 10]. При цьому родина може надавати як психотравмуючий вплив, так і бути джерелом підтримки та сприяти якнайшвидшій реабілітації хворого [11]. Однак існує і зворотна тенденція: психопатологічні й функціональні особливості хворого почасти патологічно відображаються на стані психічного здоров'я й психологічного благополуччя членів родини пацієнта, з яких найбільш ураженим контингентом $\epsilon$ діти психічно хворої людини.

Тяжке психічне захворювання у матері, яким $\epsilon$ ПШ, потужно впливає на психоемоційну сферу дитини. Широкий спектр психопатологічних проявів, якими супроводжується розвиток шизофренічного процесу, зумовлюють порушення нормальної материнсько-дитячої взаємодії зі спотворенням реалізації ключових материнських функцій: формування системи прив'язаності дитини та формування базисного відчуття безпеки.
3 огляду на наведене, метою роботи було вивчення особливостей сімейного функціонування та материнсько-дитячих відносин з точки зору дітей матерів, хворих на ПШ.

Матеріал і методи дослідження. Для досягнення зазначеної мети на базі психіатричного відділення Закарпатського обласного наркологічного диспансеру протягом 2014 - 2016 рр. обстежено 100 жінок, хворих на ПШ, та 112 їх дітей (12 жінок мали по двоє дітей). Жінки були у віці від 25 до 40 років, тривалість захворювання складала від 2 до 15 років. Вік дітей становив від 3 до 14 років, серед них було 65 дівчаток і 47 хлопчиків.

В якості групи порівняння обстежено 50 дітей зі звичайних родин, в яких у батьків не було серйозних психічних або соматичних захворювань.

Жінки були обстежені за допомогою клінікопсихопатологічного та психодіагностичного методів.

Оцінку психологічного стану дітей та сприйняття ними материнсько-дитячих стосунків здійснювали за допомогою оцінки кількісних показників за шкалами проективної методики «Кінетичний малюнок родини» Р. Бенса і С. Кауфмана, вимогою якої $\epsilon$ намалювати кожного члена родини в дії [12].

Статистична обробка даних дослідження [13] включала розвідувальний статистичний аналіз 3 метою визначення характеру розподілу ознак (тести Шапіро-Уїлка, Колмогорова-Смирнова, Лілієфорса) та формування описової статистики з використанням модуля "Descriptive Statistics» прикладного пакета програм «Statistica for Windows. Release 6.0». 
Огляди літератури, оригінальні дослідження, погляд на проблему

Результати й обговорення. У дітей з сімей здорових осіб найбільші значення показників виявлено за шкалою «Сприятлива сімейна ситуація». Середнє значення показника склало $(1,15 \pm 0,19)$ балів, що відповідає $88,5 \%$ максимального значення за цією шкалою. Високі показники за шкалою «Сприятлива сімейна ситуація» інтерпретуються як ознака сімейної гармонії, адекватної взаємодії членів сім'ї, доброзичливих та продуктивних стосунків між ними, прагнення взаємної підтримки і емоційного комфорту. Малюнки таких дітей відображали загальну діяльність усіх членів сім'ї, для них були характерні домінування людей, зображення усіх членів родини, відсутність ізольованих членів сім'ї, відсутність штрихування малюнка і добра якість ліній, адекватне розташування людей на малюнку та відсутність відображення ворожих варіантів взаємодії між ними.

Натомість, кількісні показники за негативними шкалами методики «Кінетичний малюнок сім'ї» у дітей з сімей психічно здорових осіб були низькими. Так, показник за шкалою тривожності склав $(0,62 \pm 0,25)$ балів, що відповідало низькому рівню і свідчило про відсутність ознак тривоги, неспокою, нестабільності у сімейній взаємодії. Малюнкам таких дітей були притаманні чіткі лінії з помірним натиском, відсутність стирання намальованого, гармонійне відображення всіх членів сім'ї, одинарні безперервні лінії, відсутність підкреслювань окремих деталей.

Показник за шкалою «Конфліктність у сім'ї» у дітей з сімей психічно здорових також відповідав низькому рівню: $(0,61 \pm 0,29)$ балів. Малюнки таких дітей відрізнялися відсутністю бар'єрів між фігурами на малюнку, присутністю на малюнках усіх членів сім'ї, які обернені анфас, відсутністю стирання окремих фігур, наявністю усіх важливих частин тіла у намальованих персонажів, відсутністю виділення окремих фігур та їх ізоляції, адекватною величиною окремих фігур, відповідністю вербального описання та малюнку, незначною кількістю речей на малюнках.

Ще нижчим був показник за шкалою «Почуття неповноцінності у сімейній ситуації», середнє значення якого склало $(0,45 \pm 0,28)$ балів, що відображало нормальне сприйняття дитиною свого місця в сім'ї, повноцінну участь у її функціонуванні та динамічний характер відносин у сім'ї. Малюнки таких дітей характеризувалися відповідністю розмірів зображення дитиною самої себе на малюнку його пропорціям та розмірам зображень інших членів сім'ї, розташуванням фігур у центрі аркуша, сильними безперервними лініями, відсутністю ознак ізоляції дитини від дорослих на малюнку, динамічним зображенням автора малюнку 3 оберненням його анфас.

Показник за шкалою «Ворожість у сімейній ситуації» також був низьким: $(0,67 \pm 0,28)$ балів, що свідчило про доброзичливі гармонійні стосунки між членами родини. На малюнках таких дітей були присутні всі фігури на одному боці аркуша, їм були притаманні неагресивні позиції фігур, відсутність закреслених фігур, недеформовані зображення, прямі профілі, гармонійне положення рук і пропорційне зображення пальців на руках.

Розподіл кількісних значень показників за шкалами проективної методики «Кінетичний малюнок сім'ї» у дітей з сімей психічно здорових підтвердив зазначені тенденції (рис. 1). Переважна

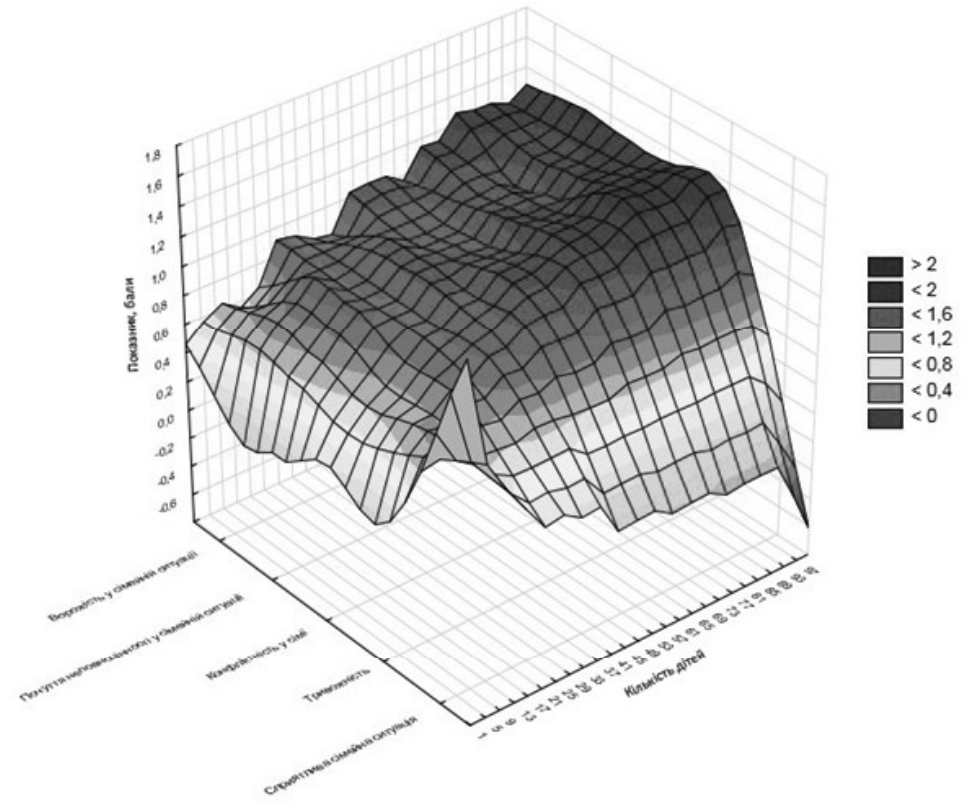

Рис. 1. 3-D діаграма розподілу значень показників за шкалами проективної методики «Кінетичний малюнок сім'ї» дітей, батьки яких $\epsilon$ психічно здоровими. 
Огляди літератури, оригінальні дослідження, погляд на проблему

більшість кількісних значень показників за шкалою «Сприятлива сімейна ситуація» (інтерквартильний діапазон) у цих дітей перебували у межах від 1,1 до 1,3 балів, випадки низьких оцінок $(0,5-$ 0,7 балів) були поодинокими, а вкрай низьких оцінок $(0,1-0,2$ бала) не виявлено; медіана значень показників за цією шкалою склала 1,2 бала. Натомість, за негативними шкалами переважна більшість показників обстежених дітей відповідала низьким значенням: за шкалою «Тривожність» від 0,4 до 0,8 бала (медіана 0,6 балів), за шкалою «Конфліктість у сім'ї» - від 0,5 до 0,8 бала (медіана 0,5 балів), за шкалою «Почуття неповноцінності у сімейній ситуації» - від 0,3 до 0,5 бала (медіана 0,4 бала), за шкалою «Ворожість у сімейній ситуації»від 0,5 до 0,9 бала (медіана 0,7 бала).

Протилежна картина була виявлена при аналізі кількісних показників за шкалами проективної методики «Кінетичний малюнок сім'ї» у дітей, матері яких хворіють на ПШ. Найнижчі показники у цій групі були виявлені за шкалою «Сприятлива сімейна ситуація", середнє значення яких склало $(0,46 \pm 0,16)$ балів. Такий низький показник свідчив про ознаки дисгармонійності у сімейних відносинах, глибокі порушення функціонування сім'ї, високий рівень стресогенності актуальних сімейних відносин. Малюнки таких дітей характеризувалися відсутністю ознак спільної діяльності всіх членів сім'ї, переважанням речей, а не людей на малюнку, відсутністю на малюнках окремих членів сім'ї (переважно хворих матерів), або зображення їх ізольовано від інших членів родини, вираженим штрихування малюнка з низькою якістю ліній. Розбіжності у кількісних значеннях показників за цією шкалою між групами дітей, матері яких хворіють на ПШ та дітей, батьки яких психічно здорові, були статистично значущими $(p<0,01)$.

На відміну від дітей зі здорових родин, дітям, матері яких хворі на ПШ, були притаманні високі показники за негативними шкалами методики «Кінетичний малюнок сім'ї». Так, середній показник за шкалою тривожності у цій групі дітей склав $(0,97 \pm 0,24)$ балів, що свідчить про високий рівень сімейної тривожності. Малюнки таких дітей характеризувалися штрихуванням, наявністю підлоги як лінії основи, наявністю ліній над малюнком, лініями з сильним натиском, стиранням малюнка, надмірною увагою до дітей на малюнку, подвійними або переривчастими лініями і підкреслюванням окремих деталей. Показники за шкалою «Тривожність» у дітей, матері яких хворіють на ПШ, були значуще вищими, ніж у дітей з сімей психічно здорових осіб $(p<0,01)$.

Аналогічно, діти, матері яких хворіють на ПШ, виявили високий рівень за шкалою «Конфліктність у сім'ї»: середнє значення показника скла- ло $(1,02 \pm 0,27)$ балів, що свідчить про виражену конфліктність у таких родинах. На малюнках виявлялися бар'єри між фігурами, стирання окремих фігур, відсутність окремих частин тіла у деяких фігур, виділення окремих фігур або їх ізоляція, неадекватна величина окремих фігур, невідповідність вербального опису і малюнка, зображення окремих членів родини (зазвичай матерів) зі спини. Розбіжності між групами дітей, матері яких хворіють на ПШ, та дітей, батьки яких психічно здорові, були статистично значущими $(p<0,01)$.

Високий показник за шкалою «Почуття неповноцінності у сімейній ситуації», що склав $(0,98 \pm 0,21)$ балів, свідчив про виражені ознаки сімейної дисгармонії. Таким малюнкам були притаманні непропорційно маленьке зображення дитиною себе на малюнку, розташування фігур у нижній частині аркуша, слабкі переривчасті лінії, ізоляція автора малюнка від інших членів родини, статична, порівняно з іншими, фігура дитиниавтора малюнка, або ж відсутність дитини-автора на малюнку чи зображення ії зі спини. Кількісний показник за шкалою «Почуття неповноцінності у сімейній ситуації» у дітей, матері яких хворіють на ПШ, був значуще більшим, ніж у дітей з родин психічно здорових осіб $(p<0,01)$.

Показник за шкалою «Ворожість у сімейній ситуації» у дітей, матері яких хворіють на ПШ, також виявився високим $(0,95 \pm 0,21$ балів) і свідчив про дисфункціональний характер сімейної взаємодії. Характерними ознаками малюнків таких дітей були наявність однієї фігури на одному боці аркуша, агресивні позиції фігур, закреслені або деформовані фігури, обернений профіль, руки, розкинуті убік, а також непропорційно довгі, підкреслені пальці. Розбіжності у показниках за цією шкалою між групами дітей, матері яких хворіють на ПШ, та дітей з сімей психічно здорових осіб, були статистично значущими $(p<0,01)$.

Аналіз особливостей розподілу кількісних значень за шкалами проективної методики «Кінетичний малюнок сім'ї» у дітей, матері яких хворіють на ПШ, суттєво відрізнявся від дітей, батьки яких $\epsilon$ психічно здоровими (рис. 2). За шкалою «Сприятлива сімейна ситуація» переважна більшість кількісних значень показників (інтерквартильний діапазон) відповідала низькому рівню (від 0,4 до 0,5 балів; медіана 0,4 бали). Натомість діапазон показників за негативними шкалами у більшості дітей, матері яких хворіють на ПШ, відповідав високому рівню. Більшість показників за шкалою «Тривожність» у цій групі перебувала в межах від 0,8 до 1,2 балів (медіана 1,0 бал), за шкалою «Конфліктість у сім'ї» - від 0,9 до 1,2 балів (медіана 1,1 балів), за шкалою «Почуття неповно- 


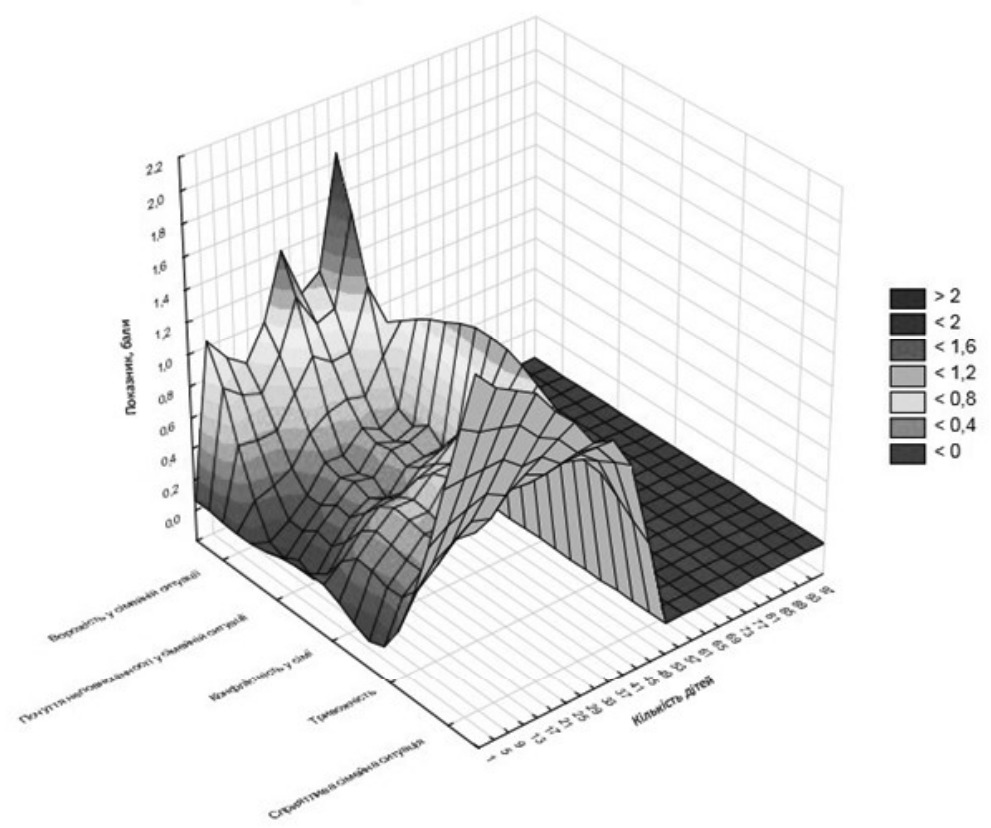

Рис. 2. 3-D діаграма розподілу значень показників за шкалами проективної методики «Кінетичний малюнок сім'ї» дітей, мати яких хворіє на ПШ.

цінності у сімейній ситуації» - від 0,9 до 1,1 балів (медіана 1,0 балів), за шкалою «Ворожість у сімейній ситуації» - від 0,85 до 1,1 балів (медіана 1,0 балів).

Висновки. У малюнках дітей знайшли відображення ознаки проявів психопатологічної симптоматики матерів, зокрема, не відображення реального складу сім'ї у малюнках, відсутність на малюнках хворої матері, зображення хворої матері на периферії малюнка, часто за реальним чи умовним бар'єром, а також зображення «віртуальних» матерів, відсутність відображення спільної діяльності членів родини, переважання на малюнках не людей, а речей. Надмірно маленькі зображення себе та членів сім'ї, як правило, у нижній частині аркуша. Ці ознаки свідчили про виражений емоційний дискомфорт, почуття самотності, депресивний настрій, почуття неповноцінності у дитини, відсутності почуття єднання з родиною, почуття відторгненості, незадоволену афіліативну потребу.

Були встановлені та кількісно оцінені значущі кореляційні зв'язки між тяжкістю психопатологічної симптоматики і показниками сімейного функціонування за даними кількісної оцінки проективної методики «Кінетичний малюнок сім'ї». Визначено тісний зв'язок порушень нормального сімейного функціонування і сприйняття дитиною родинної ситуації з тяжкістю психопатологічної симптоматики у матерів, хворих на ПШ.

У дітей, матері яких хворі на ПШ, виявлено значуще нижчі показники сімейного функціонування за шкалою «Сприятлива сімейна ситуація» (середнє значення $(0,46 \pm 0,16)$ балів, $p<0,01)$ та значуще вищі показники за шкалами «Тривожність» $(0,97 \pm 0,24)$ балів, p<0,01), «Конфліктність у сім'ї» $(1,02 \pm 0,27)$ балів, $p<0,01))$, «Почуття неповноцінності у сімейній ситуації» $(0,98 \pm 0,21$ балів, $p<0,01)$, «Ворожість у сімейній ситуації» $((0,95 \pm 0,21)$ балів, p<0,01), що свідчить про значні ознаки дисоціації у материнсько-дитячій взаємодії та сімейному функціонуванні сімей, де мати хворіє на Пш.

Обстеження за проективною методикою «Кінетичний малюнок сім'ї» дозволило виявити значні ознаки дисоціації материнсько-дитячої взаємодії та деформації сімейного функціонування сімей, де мати хворіє на ПШ. Наявність тяжкого психічного захворювання на ПШ у матері суттєво впливала на стан психоемоційної сфери дитини і спричиняла глибокі порушення сімейного функціонування.

Перспективою подальших досліджень в даній області ми бачимо розробку системи медико-психологічних заходів корекції підтримки сімейного функціонування та материнсько-дитячих стосунків в родинах, де мати хворіє на ПШ. 
Огляди літератури, оригінальні дослідження, погляд на проблему

\section{ЛІТЕРАТУРА}

1. Жизнь с шизофренией. Что делать? : краткое руководство для пациентов, страдающих шизофренией, и их родственников / Н. А. Марута, А. М. Кожина, В. И. Коростий, Л. М. Гайчук. - Харьков, 2011. - 25 с.

2. Психическое здоровье: усиление борьбы с психическими расстройствами : информационный бюллетень Всемирной организации здравоохранения. 2010. - № 220. - 12 c.

3. Юрьева Л. Н. Шизофрения: клиническое руководство для врачей / Л. Н. Юрьева. - К. : Сфера, 2010. - С. 24.

4. Tandon R. Schizophrenia: Just the Facts What we know / Rajiv Tandon, Matcheri S. Keshavan, Henry A. Nasrallah // Schizophrenia Research. - 2008. - № 102. P. 1-18.

5. Буздиган О. Г. Диференційовані підходи до психосоціальної реабілітації хворих на шизофренію з урахуванням клініко-функціональних гендерних особливостей / О. Г. Буздиган // Український вісник психоневрології. - 2016. - Т. 24, вип. 4 (89). - С. 47 - 53.

6. Животовська Л. В. Аналіз сімейного здоров'я при шизофренії в одного з батьків / Л. В. Животовська, О. А. Казаков, В.В.Борисенко // Медична психологія. 2015. - T. 10, № 3. - С. $48-51$.

7. Пшук Н. Г. Динаміка ресурсу сім'ї, де проживає хворий на параноїдну шизофренію / Н. Г. Пшук, М. В. Маркова, $€$. Я. Пшук // Український вісник психоневрології. - 2012. - Т. 20, вип. 3 (72). - С. 215.

8. Маркова М. В. Рівень функціонування родини як критерій вибору типу психотерапевтичного втручання в комплексному лікуванні хворих на параноїдну шизофренію / М.В.Маркова, В.О.Діхтяр // Український вісник психоневрології. - 2012. - Т. 20, Вип. 2 (71). С. 56-57.

9. Плевачук О. Ю. Взаємозв'язок перебігу шизофренії з психологічними особливостями мікросередовища пацієнта: автореф. дис. на здобуття наукового ступеня канд. мед. н.: 14.01.16 / Плевачук Оксана Юріївна; ДУ «Інститут неврології, психіатрії та наркології НАМН України»-Харків, 2011. - 18 с.

10. Маркова М. В. Особливості сімейної взаємодії та адаптації в родині у пацієнтів, хворих на шизофренію, з точки зору психотерапевтичного потенціалу сім'ї / М. В. Маркова, В. О. Діхтяр // Український вісник психоневрології. - 2010. - Т. 13, вып. 3 (64). - С. 133 - 134.

11. Косенко К. А. Психосоціальна реабілітація жінок, хворих на параноїдну шизофренію, при різних моделях родинної взаємодії: автореф. дис. на здобуття наукового ступеня канд. мед. н.: 14.01.16 / Косенко Корнелі Артурівна; ДУ «Інститут неврології, психіатрії та наркології НАМН України» - Харків, 2015. - 24 с.

12. Оліфірович Н. І. Психологія сімейних криз / Н. І. Оліфірович, Т. А. Зінкевич-Куземкіна, Т. Ф. Велента. - СПб. : Речь. - 2006. - 360 с.

13. Лапач С. Н. Статистические методы в медико-биологических исследованиях с использованием Excel: Экспериментальные исследования. Клинические испытания. Анализ фармацевтического рынка / С. Н. Лапач, А. В. Чубенко, П. Н. Бабич. - 2-е изд., перера6. и доп. - К. : Морион, 2001. -408 с.

\section{THE ASSESSMENT OF FAMILY SITUATION AND MOTHER-CHILD RELATIONS THROUGH THE EYES OF CHILDREN OF MOTHERS SUFFERING FROM PARANOID SCHIZOPHRENIA}

@M. O. Driuchenko

\section{Uzhhorod National University}

SUMMARY. The purpose of the work was to study the characteristics of family functioning and parent-child relationship in terms of the children of mothers suffering from paranoid schizophrenia (PS). On the basis of the psychiatric department of the Transcarpathian Regional Narcological Dispensary during 2014-2016 years 100 women with PS and their 112 children (12 women had two children) were examined. Women were examined using clinical-psychopathological and psychodiagnostic methods, children - using projective techniques «Kinetic picture of family.». There were detected violations normal close relationship of family functioning and child's perception of family situation with the severity of psychopathology in mothers suffering from PS. Children, whose mothers sufferig from PS, detected significantly lower rates of family functioning on a scale of "A favorable family situation" (mean $0.46 \pm 0.16$ points, $p<0.01$ ) and significantly higher scores on scales "Anxiety" ( $0.97 \pm 0.24$ points, $p<0.01)$, "Conflict in the family" $(1.02 \pm 0.27$ points, $p<0.01)$, "The feeling of inferiority in the family situation $(0.98 \pm 0.21$ points, $p<0.01)$, "The hostility in the family situation" $(0.95 \pm 0.21$ points, $\mathrm{p}<0.01$ ), indicating significant signs of dissociation of the parent-child interaction and family functioning families where the mother was suffering from PS. The presence of severe mental illness in the mother PS significantly affect the state of psycho-emotional sphere of the child and caused profound violation of family functioning. These data formed the basis us in the development of medical and psychological measures optimize parent-child interaction in women with PS.

KEY WORDS: paranoid schizophrenia, mother, child family situation assessment, parent-child relationships. 